\title{
Variations in osmotic adjustment and water relations of Sphaerophysa kotschyana: Glycine betaine, proline and choline accumulation in response to salinity
}

\author{
Evren Yildiztugay ${ }^{1 *}$, Ceyda Ozfidan-Konakci², Mustafa Kucukoduk ${ }^{1}$ and Yagmur Duran ${ }^{1}$
}

\begin{abstract}
Background: Sphaerophysa kotschyana Boiss. is naturally distributed in overly salty regions. The key to the completion of the life cycles of $S$. kotschyana in harsh saline soils may be hidden in changes of its osmo-protectants, but there is currently no information about the interaction between osmotic adjustment and water relations in adaptation to saline conditions. The aim of this article was to determine growth, relative growth rate (RGR), relative water content (RWC), osmotic potential $\left(\Psi_{\Pi}\right)$, photosynthetic efficiency $\left(F_{\sqrt{v}} / F_{m}\right)$, thiobarbituric acid-reactive substances (TBARS) and osmo-protectant contents [proline (Pro), choline (Cho) and glycine betaine (GB)] in S. kotschyana leaves and roots exposed to 0, 150 or $300 \mathrm{mM} \mathrm{NaCl}$ for 7 and 14 d (days).
\end{abstract}

Results: The results clearly showed that the reductions in growth, RWC, $F_{v} / F_{m}, R G R$ and $\Psi_{\Pi}$ were more pronounced at $300 \mathrm{mM}$, especially after $14 \mathrm{~d}$. In the same group, the highest increase in TBARS was recorded in roots (126\%) and leaves (31\%). The induction at $150 \mathrm{mM}$ was not as high. Therefore, roots appear to be the most vulnerable part of this plant. Moreover, S. kotschyana was able to withstand short-term low salinity.

Conclusions: The osmo-protectant accumulation in S. kotschyana as a salinity acclimation or adaptation was sufficient for toleration of low salt concentration $(150 \mathrm{mM})$. In contrast, the plants exposed to the highest $\mathrm{NaCl}$ concentration (300 mM) were not able to maintain the ability to prevent water loss because of further decrease in root/shoot ratio of fresh weight (FW) and dry weight (DW), RWC and RGR.

Keywords: Glycine betaine; Osmotic adjustment; Proline; Sphaerophysa kotschyana; Water relations

\section{Background}

About one-fifth of irrigated world agricultural lands are adversely affected by salinity, leading to induction of a wide range of perturbations at cellular and whole-plant levels (Belkheiri and Mulas, 2011). Salt stress may provoke (i) osmotic or water-deficit effect which cause reduction of water and nutrient uptake and (ii) ion-excess effect resulting from altered $\mathrm{K}^{+} / \mathrm{Na}^{+}$ratios and/or accumulation of toxic levels of $\mathrm{Na}^{+}$and $\mathrm{Cl}^{-}$. Salt stress-induced oxidative stress results from excess reactive oxygen species (ROS) formation (Munns and Tester, 2008) which damages

\footnotetext{
* Correspondence: eytugay@selcuk.edu.tr

'Department of Biology, Selcuk University, Faculty of Science, Selcuklu, 42031 Konya, Turkey

Full list of author information is available at the end of the article
}

membrane lipids, proteins and nucleic acids (Mittler, 2002). In the cellular adaptive responses of salttolerant plants, a major factor of salt tolerance mechanisms is not only acceleration of ROS scavenging systems (Chinnusamy et al., 2005), but also the ability of plant cells to adjust osmotically and to accumulate organic solutes known as compatible solutes. Compatible solutes referred to as osmo-protectants are thought to provide (i) positive effects on cellular components and membrane integrity (ii) maintenance of subcellular structure and cellular turgor and (iii) increase in the osmotic potential of the cell in plants subjected to stress conditions (Sakamoto and Murata, 2002; Ashraf and Foolad, 2007). These osmo-protectant solutes include proline (Pro) and, 
quaternary ammonium compounds such as glycine betaine (GB) (Belkheiri and Mulas, 2011).

Pro is believed to play adaptive roles in plant stress tolerance. Pro has been proposed to act as (i) a compatible osmolyte, (ii) a molecular chaperone stabilizing the structure of proteins, (iii) a mechanism to store carbon and nitrogen, (iv) to balance cell redox status and (v) a part of stress signal influencing adaptive responses (Ashraf and Foolad, 2007; Verbruggen and Hermans 2008). Among the compatible solutes, GB is a small organic metabolite abundant mainly in the chloroplast, that stabilizes the activities of enzymes/protein complexes and maintains the integrity of membranes against the damaging effects of various environmental stresses (Sakamoto and Murata, 2002). The relationship between GB content and increasing in salinity, however, is controversial. For example, GB accumulates in response to stress in many plants, including Nicotiana tabacum and Atriplex halimus (Banu et al., 2009; Belkheiri and Mulas, 2011). In contrast, contradictory data has been obtained in Trifolium alexandrinum and Salicornia dolichostachya by different researchers (Varshney et al., 1988; Katschnig et al., 2013). Therefore, GB-induced defensive responses under salt stress have still been a matter of some confusion and debate. On the other hand, choline (Cho), was synthesized by $\mathrm{GB}$ in the chloroplast, has a vital role as the precursor for phosphatidyl choline, a dominant constituent of membrane phospholipids in eukaryotes (Sakamoto and Murata, 2002). In the literature, accumulation of these compatible solutes has been extensively investigated under stress conditions, but not interaction between these osmoprotectants. Hence, the interplays among Pro, Cho and GB accumulations need to be assessed, especially in halophytes having natural defense systems against salinity.

The Salt Lake (Tuz Gölü, Turkey), the habitat of Sphaerophysa kotschyana (Fabaceae), features a unique ecosystem with its natural attractive environments and habitats for biota. Although salinity level changes with seasonal fluctuations, this lake water is extremely saline with a salt content of $32 \%$. The lake bottom is covered with a 1 to $30 \mathrm{~cm}$ thick salt layer, which has given rise to a local salt industry providing 55\% of all Turkish salt (Dengiz and Baskan, 2009). S. kotschyana is naturally distributed in overly salty regions and is well equipped to survive and complete their life cycles in saline soils (Duran et al., 2010). It has been documented in previous studies that halophytic species have developed protective or compensatory mechanisms to resist salt stress, but there is no information about tolerance and/or avoidance defined by osmotic adjustment and tighter control of water relations in the $S$. kotschyana under salinity. Interestingly, how S. kotschyana can survive to the harsh salt conditions is not well understood. The answer to this question may be hidden in the change of its osmo-protectants under salt stress, as well as in antioxidant tolerance mechanisms. Nevertheless, in roots and leaves of $S$. kotschyana, no details are known about osmotic adjustment and water relations in tolerance processes in relation to changes of these osmoprotectants.

Rather than examining the most commonly studied osmolytes individually, we focused on the unifying features associated with the accumulation of Pro, Cho and GB. Also, the present work was conducted in order to assess to defense strategies produced by leaves and roots of S. kotschyana against salt stress. With this aim, the study was undertaken to comparatively to investigate the role of the accumulation of osmo-protectants such as Pro, Cho and GB on enhancing salt tolerance. Furthermore, these parameters were correlated with some physiological and biochemical parameters including growth, relative growth rate (RGR), leaf relative water content (RWC), osmotic potential $\left(\Psi_{\Pi}\right)$, chlorophyll fluorescence $\left(\mathrm{F}_{\mathrm{v}} / \mathrm{F}_{\mathrm{m}}\right)$ and thiobarbituric acid-reactive substances (TBARS) concentration in leaves and roots of $S$. kotschyana exposed to 0,150 and $300 \mathrm{mM} \mathrm{NaCl}$ for 7 and $14 \mathrm{~d}$.

\section{Methods}

Plant material and experimental design

Sphaerophysa kotschyana Boiss. plant specimens and seeds were collected in July 2010 from around Yavsan Saltworks (Salt Lake), Konya (lat. 42 90'336“ long. 36 $51^{\prime} 649^{\prime \prime}$ at an altitude of $\left.910 \mathrm{~m}\right)$, Turkey. Taxonomic identification of the plant material was confirmed. The voucher specimen has been deposited at the Herbarium of the Department of Biology, Selcuk University, Konya, Turkey (Voucher No: EY2150). After seeds collection, immature seeds and those attacked by insects were removed and the healthy seeds were stored at $4^{\circ} \mathrm{C}$.

Sphaerophysa kotschyana seeds were sterilized with $5 \%$ sodium hypochlorite for $10 \mathrm{~min}$ and were washed thoroughly with deionized water. Then, seeds were sown into the pots filled with perlite and were grown under controlled conditions (light/dark regime of 16/8 hours (h) at $23^{\circ} \mathrm{C}, 70 \%$ relative humidity and $350 \mu \mathrm{mol} \mathrm{m} \mathrm{m}^{-2} \mathrm{~s}^{-1}$ photosynthetic photon flux density). For determination of the range of salt concentration applied to S. kotschyana, 0 (control), 150, 300 and $400 \mathrm{mM} \mathrm{NaCl}$ was used in the pretreatment experiment. The data obtained from it suggested that 150 and $300 \mathrm{mM}$ were chosen for stress-induced oxidative damage and the plants subjected to $400 \mathrm{mM} \mathrm{NaCl}$ greatly damaged and very few of them could survive against stress treatment. Seedlings were grown for $50 \mathrm{~d}$ in a fullstrength Hoagland's solution (Hoagland and Arnon, 1950). On day 50 of normal growth (applied to seedling with fiveleaf), a stress treatment was initiated by giving Hoagland's solution containing 0, 150 and $300 \mathrm{mM} \mathrm{NaCl}$. Plants were harvested on the 7 and $14 \mathrm{~d}$ of salt treatment and then stored at $-80^{\circ} \mathrm{C}$ until further analyses. 


\section{Growth and osmo-protectant accumulation of S. kotschyana under salinity}

Six random plants for each group were used for measuring changes on the growth parameter. They were separated to shoot and root fractions on 7 and $14 \mathrm{~d}$ of stress and measured with the ruler for length. Shoot and root fresh weights (FW) of seedlings were weighed. After the samples were dried at $70^{\circ} \mathrm{C}$ for $72 \mathrm{~h}$, dry weights (DW) were measured to calculate the relative growth rate (RGR). RGR values were calculated according to the following formula by Hunt et al. (2002):

$$
R G R=\left[\operatorname{In}\left(D W_{2}\right)-\operatorname{In}\left(D W_{1}\right)\right] /\left(t_{2}-t_{1}\right)
$$

where $\mathrm{DW}_{1}=$ dry weight $(\mathrm{g})$ at $\mathrm{t}_{1} ; \mathrm{DW}_{2}=$ dry weight $(\mathrm{g})$ at $t_{2}, t_{1}$; initial harvest and $t_{2}$;final harvest.

After the stress exposure period, six leaves were weighted and their FW was recorded. The samples were kept in ultrapure water for $8 \mathrm{~h}$ and then the turgid leaves (TW) were measured again. After oven drying at $75^{\circ} \mathrm{C}$ for $72 \mathrm{~h}$, DW was reported. RWC was calculated by the formula given by Smart and Bingham (1974):

$$
R W C(\%)=[(F W-D W) /(T W-D W)] \times 100
$$

After harvest on 7 and 14 d of stress treatment, chlorophyll fluorescence parameters (PSII maximum efficiency, $\mathrm{F}_{\mathrm{v}} / \mathrm{F}_{\mathrm{m}}$ ) of leaves were measured by Plant Efficiency Analyze of Hansatech, UK. This parameter provided an estimate of the maximum photochemical efficiency of the photosystem II (PSII).

Samples were homogenized by a glass rod. After centrifugation $(12000 \times \mathrm{g})$ for $10 \mathrm{~min}$, the extraction was directly used for $\Psi_{\Pi}$ determination. $\Psi_{\Pi}$ was measured by Vapro Vapor pressure Osmometer 5600. The data was collected from six samples per replicate. $\Psi_{\Pi}$ was converted to MPa according to Santa-Cruz et al. (2002) by multiplying coefficient of $2.408 \times 10^{-3}$.

Pro content was measured according to Bates et al. (1973). The samples were homogenized in 3\% sulphosalicylic acid and homogenate was filtered through filter paper. After addition of acid ninhydrin and glacial acetic acid, the mixture was heated at $100^{\circ} \mathrm{C}$. The mixture was extracted with toluene and the absorbance of the toluene fraction aspired from liquid phase was measured at $520 \mathrm{~nm}$.

Cho level was determined according to Grieve and Grattan (1983). The dry sample material was suspended in $1 \mathrm{ml}$ of distilled water and then was centrifuged at $5000 \times$ $\mathrm{g}$ for $5 \mathrm{~min}$. The supernatants were diluted 1:1 with $0.2 \mathrm{M}$ potassium phosphate buffer $(\mathrm{pH}$ 6.8). After cooling the mixtures, $20 \mu \mathrm{l}$ of cold $\mathrm{KI}-\mathrm{I}_{2}$ reagent was added. The samples were stored at $0-4^{\circ} \mathrm{C}$ for $16 \mathrm{~h}$ and then centrifuged at $10000 \times \mathrm{g}$ for $15 \mathrm{~min}$. Supernatant was removed and periodide crystals dissolved in $900 \mu \mathrm{l}$ of 1,2-dichloroethane.
After vortexing and incubating for 2-2.5 $\mathrm{h}$ at room temperature, the absorbance was recorded at $365 \mathrm{~nm}$. GB content was performed according to Grieve and Grattan (1983) with minor modifications. To obtain the supernatant for GB analysis, the procedures were the same as described as for Cho content except that the supernatants diluted 1:1 with $2 \mathrm{~N} \mathrm{H}_{2} \mathrm{SO}_{4}$. A calibration curve with reference standards of GB (5-500 $\left.\mu \mathrm{g} \mathrm{ml}^{-1}\right)$ was determined.

\section{Determination of thiobarbituric acid-reactive substances (TBARS)}

The level of lipid peroxidation was determined by thiobarbituric acid-reactive substances (TBARS) according to Madhava Rao and Sresty (2000). TBARS was calculated from the absorbance at $532 \mathrm{~nm}$ and measurements were corrected for nonspecific turbidity by subtracting the absorbance at $600 \mathrm{~nm}$. The concentration of TBARS was calculated using an extinction coefficient of $155 \mathrm{mM}^{-1} \mathrm{~cm}^{-1}$.

\section{Statistical analysis}

The experiments were repeated twice independently, and each data point was the mean of six replicates. All data obtained were subjected to a one-way analysis of variance (one way ANOVA, SPSS Statistics 20). Tukey's post-test was used to compare the treatment groups. Comparisons with $p<0.05$ were considered significantly different. In all the figures, the error bars represent standard errors of the means.

\section{Results}

Except for $7 \mathrm{~d}$ of $150 \mathrm{mM}$-treated plants, at which growth did not change significantly, salinity caused a decrease in the shoot and root length of S. kotschyana when compared with the control group. $300 \mathrm{mM} \mathrm{NaCl}$ had a significant negative effect on the growth of S. kotschyana, especially at $14 \mathrm{~d}$ (Table 1 ). As evidenced by phenotypic change of S. kotschyana, decreased length of seedlings (Figure 1A) and visible symptoms of leaf burns (Figure 1B) was more acute at $300 \mathrm{mM}$ than at $150 \mathrm{mM} \mathrm{NaCl}$. In addition, while after $14 \mathrm{~d}$ of stress, shoot length decreased by $25 \%$ in $300 \mathrm{mM} \mathrm{NaCl}$-treated plants, the reduction in root length was $29 \%$ at the same day of stress exposure. As well as root and shoot length, at $14 \mathrm{~d}, 150$ and $300 \mathrm{mM} \mathrm{NaCl}$ significantly decreased FW by $18 \%$ and $41 \%$ (root) and $23 \%$ and $41 \%$ (shoot), respectively. On the other hand, root/shoot ratio of dried plants (DW) increased in $150 \mathrm{mM}$-treated plants but decreased at $300 \mathrm{mM}$ at $7 \mathrm{~d}$ as compared to the control (Table 2).

All the salt treatments caused a significant reduction in RGR in comparison to the control group (Figure 2). Further decline (49\%) in RGR of shoots was observed in S. kotschyana treated with $300 \mathrm{mM} \mathrm{NaCl}$ for $14 \mathrm{~d}$. Similarly, the reduction in RGR of roots was more pronounced at $300 \mathrm{mM} \mathrm{NaCl}$ especially for $14 \mathrm{~d}$, at which it attained $71 \%$ of control. 
Table 1 Effects on growth [length, fresh weight (FW), dry weight (DW)] and chlorophyll fluorescence $\left(F_{v} / F_{m}\right)$ in S. kotschyana shoots and roots exposed to 0 (Control), $150 \mathrm{mM}$ and $300 \mathrm{mM} \mathrm{NaCl}$ for 7 and $14 \mathrm{~d}$

\begin{tabular}{|c|c|c|c|c|c|c|c|}
\hline \multirow[t]{2}{*}{ Groups } & \multicolumn{4}{|c|}{ Shoot } & \multicolumn{3}{|c|}{ Root } \\
\hline & Length (cm) & FW (g) & DW (g) & $\mathrm{F}_{\mathrm{v}} / \mathrm{F}_{\mathrm{m}}$ & Length $(\mathrm{cm})$ & FW (g) & DW (g) \\
\hline $0 \mathrm{mM}(7 \mathrm{~d})$ & $16.3 \pm 0.7^{a}$ & $0.61 \pm 0.05^{a}$ & $0.065 \pm 0.004^{a}$ & $0.833 \pm 0.01^{a}$ & $9.39 \pm 0.73^{a}$ & $0.13 \pm 0.06^{\mathrm{a}}$ & $0.008 \pm 0.001^{a}$ \\
\hline $150 \mathrm{mM}(7 \mathrm{~d})$ & $16.0 \pm 0.8^{a}$ & $0.55 \pm 0.01^{\mathrm{a}}$ & $0.061 \pm 0.012^{\mathrm{a}}$ & $0.841 \pm 0.01^{\mathrm{a}}$ & $9.10 \pm 0.42^{\mathrm{a}}$ & $0.12 \pm 0.08^{\mathrm{a}}$ & $0.008 \pm 0.001^{a}$ \\
\hline 300 mM (7d) & $14.3 \pm 0.6^{b}$ & $0.43 \pm 0.01^{b}$ & $0.059 \pm 0.002^{\mathrm{a}}$ & $0.847 \pm 0.01^{\mathrm{a}}$ & $7.43 \pm 0.31^{b}$ & $0.09 \pm 0.01^{b}$ & $0.007 \pm 0.001^{a}$ \\
\hline $0 \mathrm{mM}(14 \mathrm{~d})$ & $20.4 \pm 0.77^{a}$ & $0.69 \pm 0.04^{a}$ & $0.09 \pm 0.001^{\mathrm{a}}$ & $0.843 \pm 0.01^{a}$ & $12.4 \pm 0.83^{\mathrm{a}}$ & $0.17 \pm 0.07^{a}$ & $0.011 \pm 0.0020^{a}$ \\
\hline $150 \mathrm{mM}(14 \mathrm{~d})$ & $19.0 \pm 1.35^{\mathrm{a}}$ & $0.53 \pm 0.02^{b}$ & $0.06 \pm 0.005^{b}$ & $0.844 \pm 0.01^{\mathrm{a}}$ & $9.8 \pm 0.63^{b}$ & $0.14 \pm 0.01^{b}$ & $0.010 \pm 0.0002^{a}$ \\
\hline $300 \mathrm{mM}(14 \mathrm{~d})$ & $15.2 \pm 1.15^{b}$ & $0.41 \pm 0.03^{c}$ & $0.05 \pm 0.008^{c}$ & $0.781 \pm 0.01^{b}$ & $8.8 \pm 0.57^{b}$ & $0.10 \pm 0.01^{b}$ & $0.006 \pm 0.0001^{b}$ \\
\hline
\end{tabular}

Letters $\mathrm{a}, \mathrm{b}$ and $\mathrm{c}$ indicate a statistically significant difference between treated plants and untreated plants. The different letters are significantly different $(P<0.05)$.

As is evident from Figure 3, RWC was close to the control group after $7 \mathrm{~d}$ of stress, but it decreased at $14 \mathrm{~d}$. RWC was $10 \%$ and $17 \%$ lower than in the control group at 150 and $300 \mathrm{mM} \mathrm{NaCl}$ at $14 \mathrm{~d}$, respectively.

As is clear from Table $1, \mathrm{~F}_{\mathrm{v}} / \mathrm{F}_{\mathrm{m}}$ did not change at $150 \mathrm{mM} \mathrm{NaCl}$ throughout the experiment and PS-II efficiency was preserved. However, at $300 \mathrm{mM} \mathrm{NaCl}, \mathrm{F}_{\mathrm{v}} / \mathrm{F}_{\mathrm{m}}$ decreased after $14 \mathrm{~d}$ of stress (7\%).

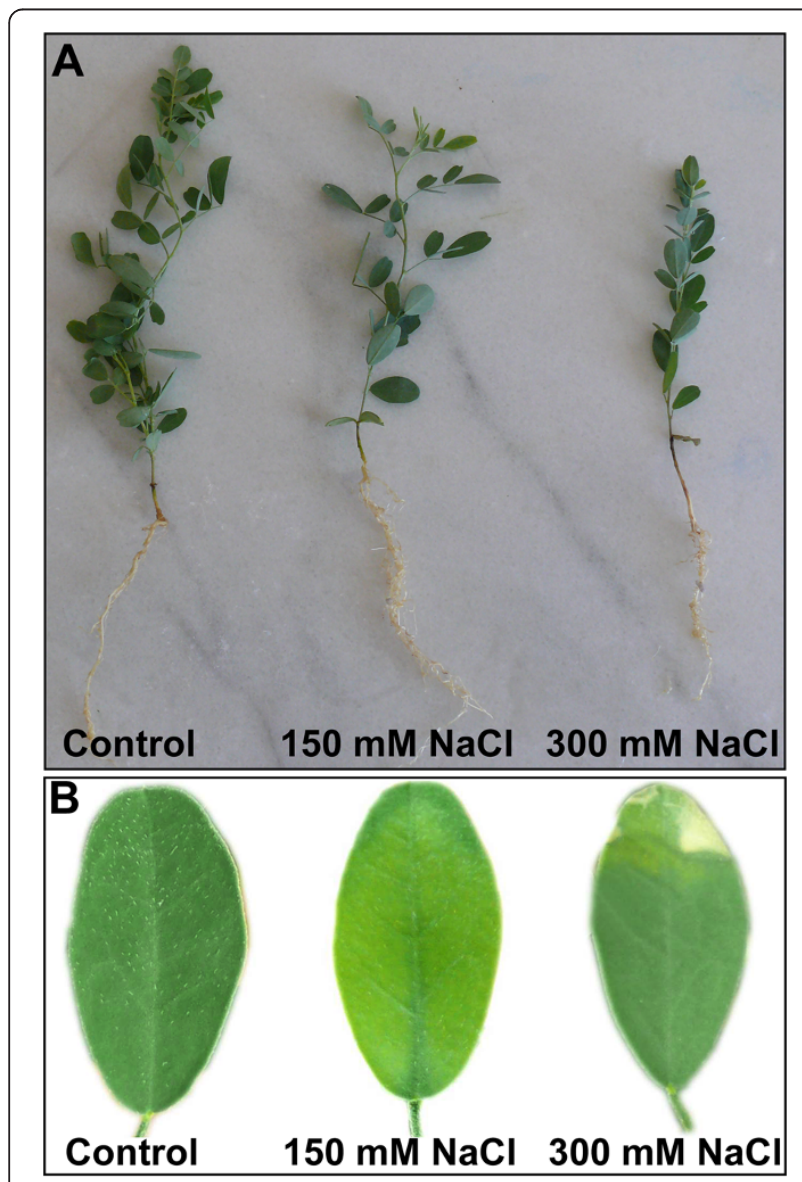

Figure 1 Effects on length of seedlings (A) and leaf burns (B) in S. kotschyana exposed to 0 (Control), $150 \mathrm{mM}$ and $300 \mathrm{mM}$ $\mathrm{NaCl}$ for $14 \mathrm{~d}$.
$\Psi_{\Pi}$ in leaves and roots showed the same changes at both sampling days and salt concentrations (Figure 4). The $\Psi_{\Pi}$ in leaves decreased after $7 \mathrm{~d}$ exposure to 150 and $300 \mathrm{mM} . \Psi_{\Pi}$ in leaves dropped from -1.1 (control levels) to $-1.6 \mathrm{MPa}$ after $14 \mathrm{~d}$ of $300 \mathrm{mM} \mathrm{NaCl}$. Similarly, $300 \mathrm{mM} \mathrm{NaCl}$ caused more reduction in root $\Psi_{\Pi}$ $(-1.2 \mathrm{MPa})$ than that of control $(-0.9 \mathrm{MPa})$ at $14 \mathrm{~d}$. However, the reductions were more pronounced in leaves than in roots. For example, $300 \mathrm{mM} \mathrm{NaCl}$ yielded a larger $\Psi_{\Pi}$ reduction (46\%) in S. kotschyana leaves at 14 d when compared to the $\Psi_{\Pi}$ of roots (33\%).

Pro, Cho and GB contents in leaves and roots increased with salinity during the experimental period (Figure 5). Even greater contents of the osmo-protectants were observed in $300 \mathrm{mM}$-treated leaves at 14 d (Figure 5A, C, E). Under $150 \mathrm{mM}$, Pro in roots was close to control level at $7 \mathrm{~d}$ (Figure 5B). On the other hand, except this group, 150 and $300 \mathrm{mM} \mathrm{NaCl}$ increased Pro relative to control group, more so after $14 \mathrm{~d}$ exposure to $300 \mathrm{mM}$ (274\% and $247 \%$, leaves and roots, respectively). Cho accumulation showed a significant increase in response to salinity in both leaves and roots. At $150 \mathrm{mM} \mathrm{NaCl}$, Cho increased 1.9 and 3 fold in leaves after 7 and $14 \mathrm{~d}$ of the beginning of the salinity treatments as compared with the control, respectively (Figure 5C). Also, Cho content increased in roots of stress-treated $S$. kotschyana, but this induction was as high as that in leaves (Figure 5D). For example, when $\mathrm{NaCl}$ stress became more severe, the increase in leaves (315\%) was much greater than in root $(62 \%)$ at $14 \mathrm{~d}$. On the other hand, GB in leaves markedly increased in response to 150 and $300 \mathrm{mM} \mathrm{NaCl}$ and accumulated to significantly higher levels at the higher salt concentration (Figure 5E). GB levels in roots did not change with salinity at $7 \mathrm{~d}$ (Figure 5F). In contrast, GB concentration showed a dramatic increase in response to $300 \mathrm{mM}$. The highest induction in roots (84\%) was obtained at $14 \mathrm{~d}$.

Except in leaves of $150 \mathrm{mM}$-treated plants at $7 \mathrm{~d}$, TBARS in leaves and roots increased with salinity as compared to control group (Figure 6A, B). Moreover, $300 \mathrm{mM} \mathrm{NaCl}$ induced the maximum rate of lipid peroxidation in membranes and caused an increase in damage by $31 \%$ in leaves 
Table 2 Effects on root/shoot ratio of length, fresh weight (FW) and dry weight (DW) in S. kotschyana shoots and roots exposed to 0 (Control), $150 \mathrm{mM}$ and $300 \mathrm{mM} \mathrm{NaCl}$ for 7 and $14 \mathrm{~d}$ (days)

\begin{tabular}{|c|c|c|c|c|c|c|}
\hline & \multicolumn{3}{|c|}{7 Days } & \multicolumn{3}{|c|}{14 Days } \\
\hline & $0 \mathrm{mM}$ & $150 \mathrm{mM}$ & $300 \mathrm{mM}$ & $0 \mathrm{mM}$ & $150 \mathrm{mM}$ & $300 \mathrm{mM}$ \\
\hline Root length/shoot length & $0.576 \pm 0.04^{a}$ & $0.568 \pm 0.02^{a}$ & $0.519 \pm 0.01^{\mathrm{b}}$ & $0.607 \pm 0.02^{a}$ & $0.515 \pm 0.03^{b}$ & $0.528 \pm 0.002^{c}$ \\
\hline Root FW/shoot FW & $0.213 \pm 0.01^{\mathrm{a}}$ & $0.218 \pm 0.01^{\mathrm{a}}$ & $0.209 \pm 0.02^{b}$ & $0.246 \pm 0.02^{\mathrm{a}}$ & $0.264 \pm 0.03^{b}$ & $0.243 \pm 0.003^{a}$ \\
\hline Root DW/shoot DW & $0.123 \pm 0.01^{\mathrm{a}}$ & $0.131 \pm 0.02^{c}$ & $0.118 \pm 0.02^{b}$ & $0.122 \pm 0.02^{\mathrm{a}}$ & $0.167 \pm 0.03^{c}$ & $0.12 \pm 0.002^{\mathrm{a}}$ \\
\hline
\end{tabular}

Letters $\mathrm{a}, \mathrm{b}$ and $\mathrm{c}$ indicate a statistically significant difference between treated plants and untreated plants. The different letters are significantly different $(P<0.05)$.

at $14 \mathrm{~d}$ when compared to the control. On the other hand, the highest increase in TBARS in roots was $126 \%$ at the same days of stress.

\section{Discussion}

Growth of S. kotschyana was significantly reduced with $\mathrm{NaCl}$ treatments in a dose-dependent manner, which is in agreement with different studies (Athar et al., 2009; Noreen et al., 2010). This change might be due to toxic effects of $\mathrm{Na}^{+}$and $\mathrm{Cl}^{-}$and unbalancing of nutrient uptake. A previous study carried out with cotton (Meloni et al., 2003) also showed that shoot growth was more inhibited by $\mathrm{NaCl}$ than that of root. In our experiment, while the reduction percentages of root lengths were parallel to the results of previous studies, changes in FW and DW were in conflict. On the other hand, increased root/shoot ratio appears to be an adaptation to salinity, resulting in a more efficient water and nutrient uptake under stress (Gorham et al., 1985), supporting our findings, especially in $150 \mathrm{mM} \mathrm{NaCl}$-treated plants.

Information on the relationship between salt tolerance and RWC, RGR or $\Psi_{\Pi}$ would be useful to use these parameters as selection criteria in water regulations. After $14 \mathrm{~d}$ of stress in S. kotschyana, the decrease in RWC is in confirmation of results reported by Sairam et al. (2002). The decrease in RWC resulted a loss of turgor and then limited water availability for cell extension processes (Katerji et al., 2003). In the present study, the inhibition in RGR was stronger in $300 \mathrm{mM} \mathrm{NaCl}$-treated roots of S. kotschyana, demonstrating results of FW and DW. This result was well in agreement with those of Kim et al. (2004) and Lacerda et al. (2005). $300 \mathrm{mM}$ might inhibit the growth rate of $S$. kotschyana due to the osmotic and ionic effects of salinity in line with the findings of Sun et al. (2009). This allows soil water uptake and sustains the turgor potential. In S. kotschyana exposed to salinity, the increase in osmolytes was compatible with the reduction in $\Psi_{\Pi}$.

$\mathrm{F}_{\mathrm{v}} / \mathrm{F}_{\mathrm{m}}$ is used as chlorophyll fluorescence parameter, closely correlated to photochemical efficiency of PSII and is a sensitive indicator of photosynthetic performance in plants (Kalaji et al., 2010). This parameter is thought to play a vital role in the process of photoinhibition when plants are exposed to drought and salt stresses (Maxwell and Johnson, 2000). $\mathrm{F}_{\mathrm{v}} / \mathrm{F}_{\mathrm{m}}$ is close to 0.83 for most plants grown without stress (Bjorkman and Demmig 1987). Values lower than 0.83 suggest that plants are growing under stress and that PSII reaction centers are damaged which, in turn, is connected with reduced effectiveness of electron transport (Basu et al., 1998) when plants are grown under salinity. Similar to this, $\mathrm{F}_{\mathrm{v}} / \mathrm{F}_{\mathrm{m}}$ showed a significantly decrease after $14 \mathrm{~d}$ exposure to $300 \mathrm{mM} \mathrm{NaCl}$. However, $150 \mathrm{mM} \mathrm{NaCl}$ did not change the $\mathrm{F}_{\mathrm{v}} / \mathrm{F}_{\mathrm{m}}$ of $S$. kotschyana. It is reported by
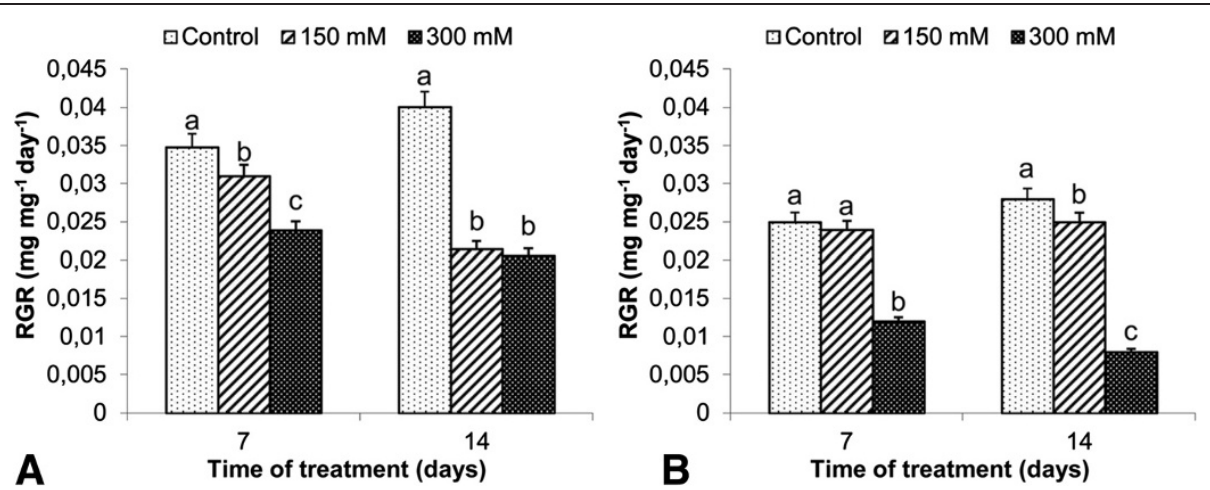

Figure 2 Effects on relative growth rate (RGR, $\mathrm{mg} \mathrm{mg}^{-1} \mathrm{~d}^{-1}$ ) in S. kotschyana shoots (A) and roots (B) exposed to 0 (Control), $150 \mathrm{mM}$ and $\mathbf{3 0 0} \mathrm{mM} \mathrm{NaCl}$ for $\mathbf{7}$ and $\mathbf{1 4} \mathbf{d}$ are shown. Vertical bars indicate $\pm S E$ and values sharing a common letter are not significantly different at $P>0.05$. 


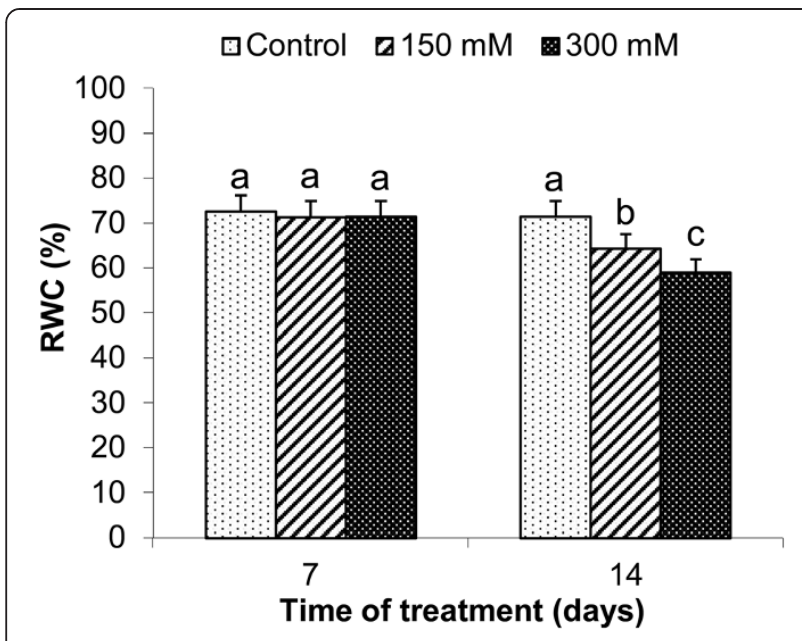

Figure 3 Effects on relative water content (RWC,\%) in S. kotschyana leaves exposed to 0 (Control), $150 \mathrm{mM}$ and $300 \mathrm{mM} \mathrm{NaCl}$ for 7 and $14 \mathrm{~d}$. Vertical bars indicate $\pm S E$ and values sharing a common letter are not significantly different at $P>0.05$.

Sakamoto and Murata (2002) that the protection of PSII complexes from oxidative damage might be connected with increased GB content under salt stress.

Pro maintains $\mathrm{NAD}^{+} / \mathrm{NADH}$ ratios necessary for respiratory and photosynthetic processes, enhances photosystem II-mediated photochemical activity in thylakoid membranes and prevents the photoinhibitory loss of photochemical activity under stress conditions (Kavi Kishor et al., 2005). In our experiment, a dramatic increase in Pro content in the plants exposed to the highest $\mathrm{NaCl}$ concentration could contribute to the lack of notable change in photosynthetic efficiency. Supporting findings come from other plants such as sugar beet (Ghoulam et al., 2002) where salt stress results in extensive Pro accumulation. Also, it has been reported in salt treated Anacardium occidentale that Pro accumulation is higher in leaves than roots (Alvarez-Pizarro et al., 2009) which is in accordance to the results obtained in this experiment. Recent experimental evidence has demonstrated that plant species able to synthesize GB may also accumulate other organic compatible solutes, such as Pro (Martinez et al., 2005). GB has been shown in vitro (i) to stabilize membranes of the oxygen evolving photosystem II complex and (ii) to accumulate in the cytoplasm to balance the accumulation of solutes and ions in the vacuole during osmotic adjustment (Papageorgiou and Murata, 1995). There was a significant positive correlation among Pro, GB contents and the extent of tolerance to oxidative in S. kotschyana. However, it seems to be that Pro had more contribution than GB regarding osmotic adjustment. Another contributor to osmotic adjustment in salt stressed-S. kotschyana was Cho. Cho is synthesized from GB in the chloroplast. Like Pro and GB, Cho increased with salinity treatments in S. kotschyana as suggested by Varshney et al. (1988). Therefore, the induced contents of these osmo-protectants were compatible with each other under salinity. Also, due to the increase in Pro, $\mathrm{GB}$ and Cho contents in leaves of $150 \mathrm{mM}$-treated plants, accumulation of these osmo-protectants might be sufficient for protection of the photosynthetic apparatus and water status against oxidative damage.

Increases in TBARS have been reported in salt stresstreated plants (Sudhakar et al., 2001; Sairam et al., 2002). This increase is related to the amount of stress and is well correlated with lipid membrane damage. Roots of $S$. kotschyana seemed to be more affected by the $\mathrm{NaCl}$ induced oxidative stress, as evidenced by a considerable increase in TBARS, as well as by the further decrease in RGR. Additionally, roots had a lower induction in osmoprotectant accumulation than did leaves.

\section{Conclusions}

This is the first report to provide insights into the mechanisms of stress tolerance and to compare water relations, osmotic adjustment and photosynthetic alterations in response to salinity of $S$. kotschyana. The results clearly showed that roots would appear to be the most vulnerable part of this plant, as they were directly exposed to the salt. Thus, in summary, the degree of osmotic adjustment in

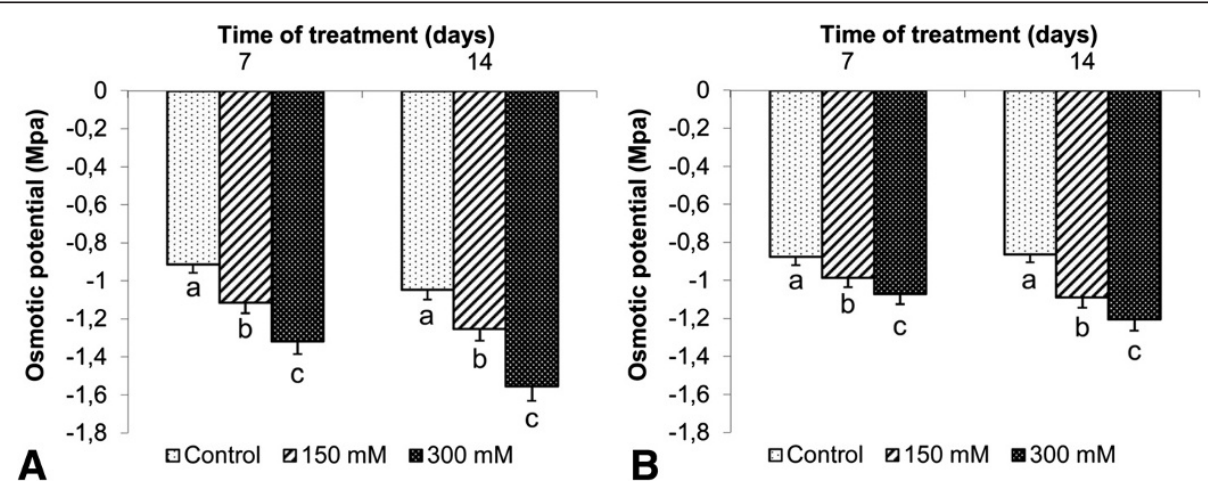

Figure 4 Effects on osmotic potential $\left(\Psi_{\Pi}, \mathrm{MPa}\right)$ in S. kotschyana leaves $(\mathrm{A})$ and roots (B) exposed to 0 (Control), $150 \mathrm{mM}$ and $300 \mathrm{mM}$ $\mathrm{NaCl}$ for $\mathbf{7}$ and $14 \mathrm{~d}$ are shown. Vertical bars indicate $\pm \mathrm{SE}$ and values sharing a common letter are not significantly different at $P>0.05$. 

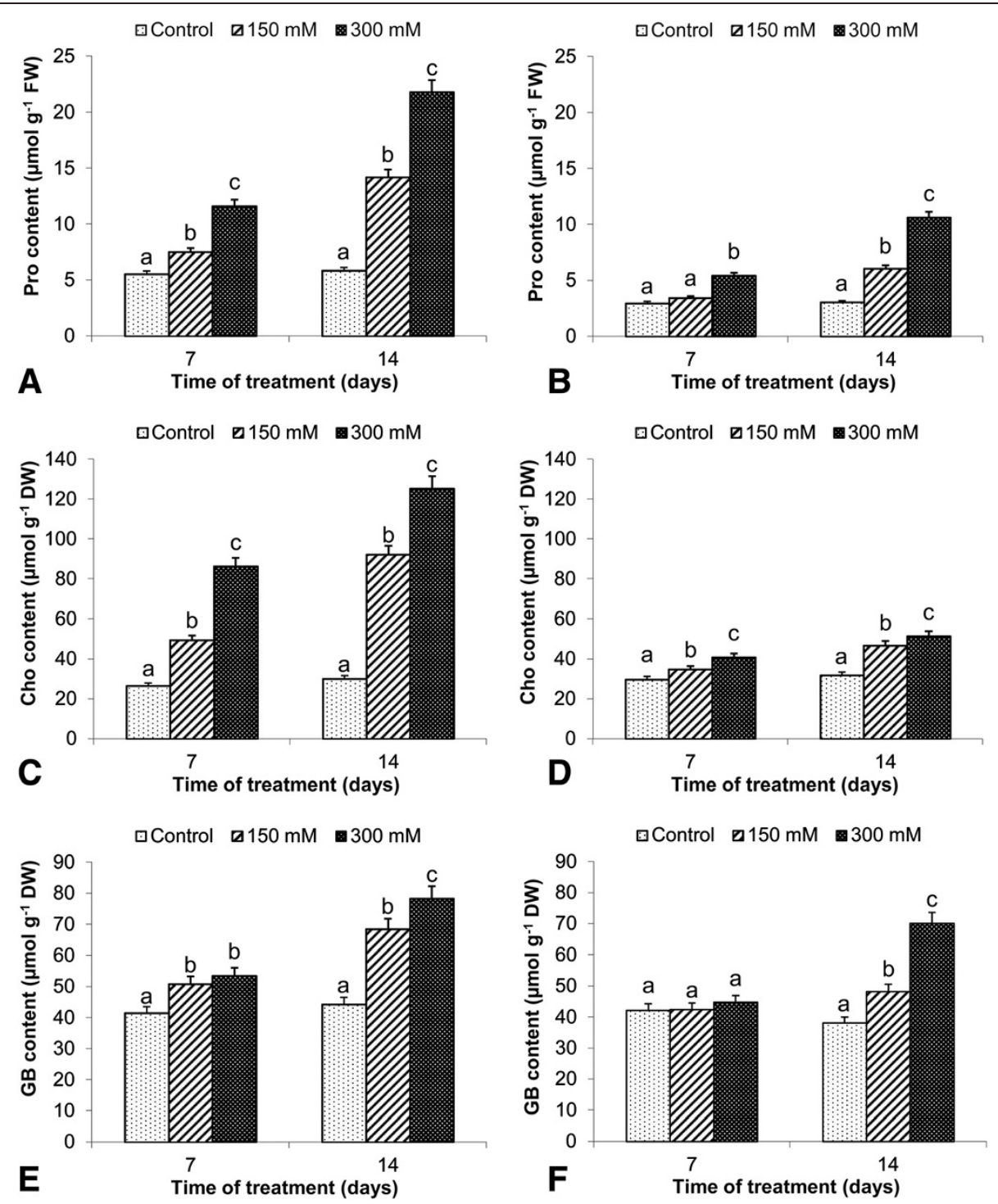

Figure 5 Effects on proline (Pro, $\mu \mathrm{mol} \mathrm{g}^{-1} \mathrm{FW}$ ), choline (Cho, $\mu \mathrm{mol} \mathrm{g}{ }^{-1} \mathrm{DW}$ ) and glycine betaine (GB, $\mu \mathrm{mol} \mathrm{g}{ }^{-1} \mathrm{DW}$ ) in S. kotschyana leaves $(A, C, E)$ and roots (B, D, F) exposed to 0 (Control), $150 \mathrm{mM}$ and $300 \mathrm{mM} \mathrm{NaCl}$ for $\mathbf{7}$ and $14 \mathrm{~d}$ are shown. Vertical bars indicate $\pm S E$ and values sharing a common letter are not significantly different at $P>0.05$.

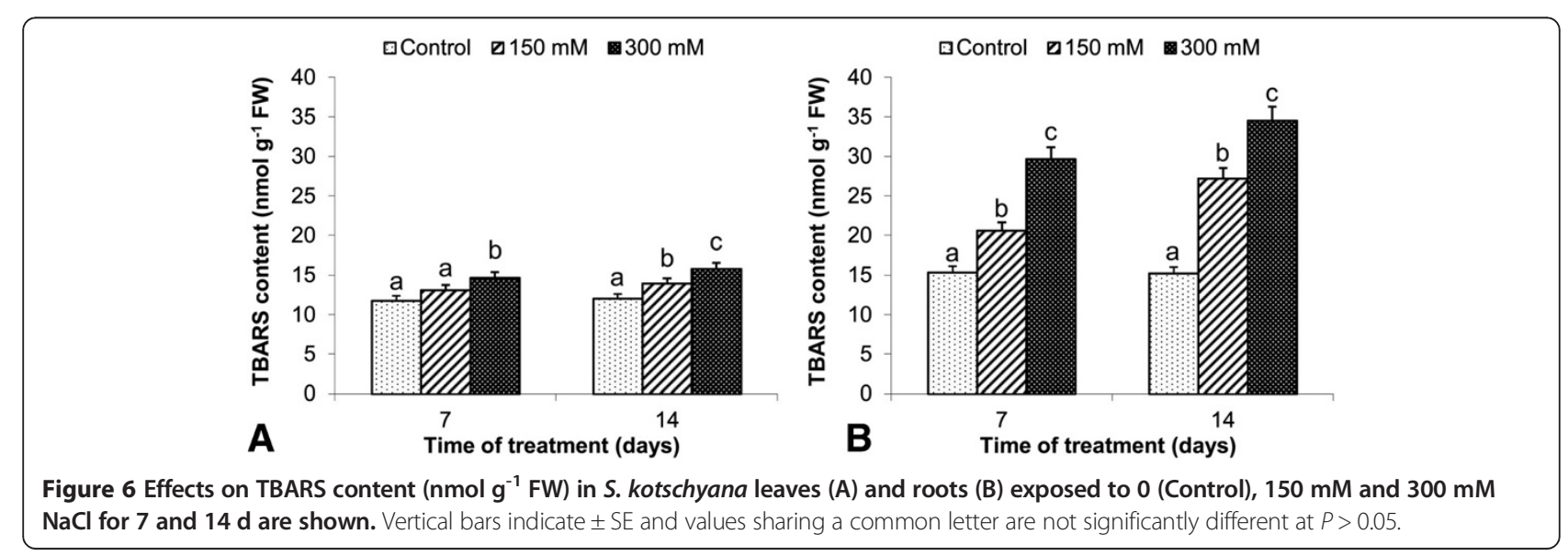


leaves was greater than roots with the increase in $\mathrm{NaCl}$ concentration. Any increase in osmotic adjustment under saline conditions might likely be a result of increase in the ions in the vacuole. Our results support the idea that leaves and roots of $S$. kotschyana were well-adapted to saline environments, as suggested by maintenance of a high root/shoot ratio, lower increase in TBARS accumulation, lower decline in RGR, plant growth parameters and $\Psi_{\Pi}$ especially on $7 \mathrm{~d}$. Therefore, S. kotschyana could withstand both short-term salinity and low salt concentration. Therefore, the amounts of osmo-protectants in S. kotschyana's response to salinity acclimation or adaptation were sufficient to for tolerance of low salt concentration $(150 \mathrm{mM})$. In contrast, in the plants exposed to $300 \mathrm{mM} \mathrm{NaCl}$, despite the increase in osmolyte accumulation, was not able to maintain the ability to prevent water loss and became oxidatively damaged as demonstrated by a further decrease in growth, root/shoot ratio, RGR, RWC and a decline in antioxidant enzymes activity.

\section{Abbreviations}

Cho: Choline; GB: Glycine betaine; Pro: Proline; RGR: Relative growth rate; RWC: Relative water content; TBARS: Thiobarbituric acid-reactive substances.

\section{Competing interests}

The authors declare that they have no competing interests.

\section{Authors' contributions}

EY, CO-K and MK designed the experiment. EY, CO-K and YD contributed extensively to the work presented in this paper and were also responsible for growing, sampling, data analysis/collection and interpretation of Sphaerophysa kotschyana seedlings. All authors read and approved the final manuscript.

\section{Acknowledgements}

Financial support for this work was provided by Selcuk University Scientific Research Projects Coordinating Office (Project number: 11401069).

\section{Author details}

'Department of Biology, Selcuk University, Faculty of Science, Selcuklu, 42031 Konya, Turkey. ${ }^{2}$ Department of Molecular Biology and Genetics, Faculty of Science, Necmettin Erbakan University, Meram, 42090 Konya, Turkey.

Received: 15 April 2013 Accepted: 30 August 2013

Published: 17 January 2014

\section{References}

Alvarez-Pizarro JC, Gomes-Filho E, Lacerda CF, Alencar NLM, Prisco JT (2009) Salt-induced changes on $\mathrm{H}^{+}$-ATPase activity, sterol and phospholipid content and lipid peroxidation of root plasma membrane from dwarf-cashew (Anacardium occidentale L.) seedlings. Plant Growth Regul 59:125-135

Ashraf M, Foolad MR (2007) Roles of glycinebetaine and proline in improving plant abiotic stress tolerance. Environ Exp Bot 59:206-216

Athar H, Ashraf M, Wahid A, Jamil A (2009) Inducing salt tolerance in canola (Brassica napus L.) by exogenous application of glycinebetaine and proline: response at the initial growth stages. Pak J Bot 41:1311-1319

Banu M, Hoque M, Watanabe-Sugimoto M, Matsuoka K, Nakamura Y, Murata N (2009) Proline and glycinebetaine induce antioxidant defense gene expression and suppress cell death in cultured tobacco cells under salt stress. J Plant Physiol 166:146-156

Basu PS, Sharma A, Sukumaran NP (1998) Changes in net photosynthetic rate and chlorophyll fluorescence in potato leaves induced by water stress. Photosynthetica 35:13-19

Bates L, Waldrenn R, Teare I (1973) Rapid determination of free proline for water-stress studies. Plant Soil 39:205-207
Belkheiri O, Mulas M (2011) The effects of salt stress on growth, water relations and ion accumulation in two halophyte Atriplex species. Environ Exp Bot 86:17-28

Bjorkman O, Demmig B (1987) Photon yield of $\mathrm{O}_{2}$ evolution and chlorophyll fluorescence characteristics at $77 \mathrm{~K}$ among vascular plants of diverse origins. Planta 170:489-504

Chinnusamy V, Jagendorf A, Zhu J (2005) Understanding and improving salt tolerance in plants. Crop Sci 45:437-448

Dengiz O, Baskan O (2009) Land quality assessment and sustainable land use in Salt Lake (Tuz Gölü) specially protected area. J Environ Monitor 148:233-243

Duran A, Martin E, Ozturk M, Cetin O, Dinc M, Ozdemir A (2010) Morphological, karyological and ecological features of halophytic endemic Sphaerophysa kotschyana Boiss. (Fabaceae) in Turkey. Biogeosciences 3:163-169

Ghoulam C, Foursy A, Fares K (2002) Effects of salt stress on growth inorganic ions and proline accumulation in relation to osmotic adjustment in five sugar beet cultivars. Environ Exp Bot 47:39-50

Gorham J, Wyn Jones RG, McDonnell E (1985) Some mechanisms of salt tolerance in crop plants. Plant Soil 89:15-40

Grieve CM, Grattan SR (1983) Rapid assay for the determination of water soluble quaternary ammonium compounds. Plant Soil 70:303-307

Hoagland DR, Arnon DI (1950) The water culture method for growing plants without soil. Calif AES Bull 347:1-32

Hunt R, Causton DR, Shipley B, Askew AP (2002) A modern tool for classical plant growth analysis. Ann Bot 90:485-488

Kalaji HM, Govindje E, Bosa K, Koscielniak J, Zuk-Golaszewska K (2010) Effects of salt stress on photosystem II efficiency and $\mathrm{CO}_{2}$ assimilation of two Syrian barley landraces. Environ Exp Bot 73:64-72

Katerji N, van Hoorn JW, Hamdy A, Mastrorilli M (2003) Salinity effect on crop development and yield, analysis of salt tolerance according to several classification methods. Agric Water Manage 62:37-66

Katschnig D, Broekman R, Rozema J (2013) Salt tolerance in the halophyte Salicornia dolichostachya Moss: growth, morphology and physiology. Environ Exp Bot 92:32-42

Kavi Kishor PB, Sangam S, Amrutha RN, Laxmi PS, Naidu KR, Rao KRSS, Sreenath R, Reddy KJ, Theriappan P, Sreenivasulu N (2005) Regulation of proline biosynthesis, degradation, uptake and transport in higher plants: its implications in plant growth and abiotic stress tolerance. Curr Sci 88:424-438

Kim JY, Lee SC, Jung KH, An G, Kim SR (2004) Characterization of a cold responsive gene, OsPTR1, isolated from the screening of $\beta$-glucuronidase (GUS)-gene trapped rice. J Plant Biol 47:133-141

Lacerda CF, Cambraia J, Oliva MA, Ruiz HA (2005) Changes in growth and insolute concentrations in sorghum leaves and roots during salt stress recovery. Environ Exp Bot 54:69-76

Madhava Rao KV, Sresty TVS (2000) Antioxidative parameters in the seedlings of pigeon pea (Cajanus cajan L. Millspaugh) in response to $\mathrm{Zn}$ and Ni stresses. Plant Sci 157:113-128

Martinez JP, Kinet JM, Bajii M, Lutts S (2005) NaCl alleviates polyethylene glycolinduced water stress in the halophyte species Atriplex halimus L. J Exp Bot 419:2421-2431

Maxwell K, Johnson GN (2000) Chlorophyll fluorescence: a practical guide. J Exp Bot 51:659-668

Meloni DA, Oliva MA, Martinez CA, Cambraia J (2003) Photosynthesis and activity of superoxide dismutase, peroxidase and glutathione reductase in cotton under salt stress. Environ Exp Bot 49:69-76

Mittler R (2002) Oxidative stress, antioxidants and stress tolerance. Trends Plant Sci 7:405-410

Munns R, Tester M (2008) Mechanisms of salinity tolerance. Annu Rev Plant Biol 59:651-681

Noreen Z, Ashraf M, Akram NA (2010) Salt-induced regulation of some key antioxidant enzymes and physio-biochemical phenomena in five diverse cultivars of turnip (Brassica rapa L.). J Agron Crop Sci 196:273-285

Papageorgiou GC, Murata N (1995) The unusually strong stabilizing effects of glycine betaine on the structure and function of the oxygen-evolving photosystem complex. Photosynth Res 44:243-252

Sairam RK, Veerabhadra RK, Srivastava GC (2002) Differential response of wheat genotypes to long term salinity stress in relation to oxidative stress, antioxidant activity and osmolyte concentration. Plant Sci 163:1037-1046

Sakamoto M, Murata N (2002) The role of glycinebetaine in the protection of plants from stress: clues from transgenic plants. Plant Cell Environ 25:163-171 
Santa-Cruz A, Martinez-Rodriguez MM, Perez-Alfocea F, Romero-Aranda R, Bolarin CM (2002) The rootstock effect on the tomato salinity response depends on the shoot genotype. Plant Sci 162:825-831

Smart RE, Bingham GE (1974) Rapid estimates of relative water content. Plant Physiol 53:258-260

Sudhakar C, Lakshmi A, Giridarakumar S (2001) Changes in the antioxidant enzyme activities in two high yielding genotypes of mulberry (Morus alba L.) under $\mathrm{NaCl}$ salinity. Plant Sci 161:613-619

Sun J, Chen SL, Dai SX, Wang RG, Li NY, Shen X, Zhou XY, Lu KF, Zheng SJ, Hu ZM, Zhang ZK, Song J, Xu Y (2009) NaCl-induced alternations of cellular and tissue ion fluxes in roots of salt-resistant and salt-sensitive poplar species. Plant Physiol 149:1141-1153

Varshney KA, Gangwar LP, Goel N (1988) Choline and betaine accumulation in Trifolium alexandrinum $\mathrm{L}$. during salt stress. Egypt J Bot 31:81-86

Verbruggen N, Hermans C (2008) Proline accumulation in plants: a review. Amino Acids 35:753-759

doi:10.1186/1999-3110-55-6

Cite this article as: Yildiztugay et al:: Variations in osmotic adjustment and water relations of Sphaerophysa kotschyana: Glycine betaine, proline and choline accumulation in response to salinity. Botanical Studies 2014 55:6

\section{Submit your manuscript to a SpringerOpen ${ }^{\circ}$} journal and benefit from:

- Convenient online submission

- Rigorous peer review

- Immediate publication on acceptance

- Open access: articles freely available online

- High visibility within the field

- Retaining the copyright to your article 